\title{
Thoughts on Translating Rose Swallow's Story
}

\author{
Patricia Ningewance Nadeau \\ Lac Seul, Ontario
}

I learned English at age 6. I'm 70 now. I spoke Ojibwe easily during my early years. I remember thinking that there was no concept I couldn't express in my language at age 14. Now I can't say that. I've been speaking mostly English since I've been in my 20s. The longer I live in the city, the more English I speak and the less fluent I become in my language. I have to think first now before forming a complex sentence.

I went to residential school in Sault Ste. Marie, Ontario as a teenager with Cree girls from James Bay area and northern Quebec. Maybe I know Rose Swallow. I lived a similar lifestyle that she did with her grandparents. I experienced reserve life that she describes - the skidoos, the HBC store, etc.

I enjoyed the description of the 'old time' lifestyle. The parts that made me uneasy were the descriptions of full-blown diabetes. I see too much of that in my own home community. I see young men in their 30s with amputated limbs. They're on dialysis. My own family members are diabetic including my son. I am told I am borderline but actually I think I am there already. So translating these stories about diabetes is too close to home. However, the message is a hopeful one. In Rose's story, her response to having diabetes is very proactive. She is also fortunate to have found a partner who is a good support. Working to fight diabetes becomes her life work.

Now I'd like to talk about the translation itself. I do technical translation and literature translation. In technical translations, there is no thought given to whether a reader will need an almost literal translation to further his/her study of the language. The object is communication. With artistic translation, I must look at communicating the intent of the story with some free translation but also attempt to stay with the original version so a learner can go back and forth without consulting a dictionary too much.

The Ojibwe and Cree languages are polysynthetic languages. They are very different from the European languages that we are familiar with (English, French, Spanish, etc.). One Ojibwe word can also be a sentence because it contains the subject, verb, object and many modifiers. Reduplication is commonly used to convey repeated or prolonged action or state of being.

1. Example:

Nin-gii-wii-gichi-babaamose-mi-naaban. We had wanted to walk around lots.

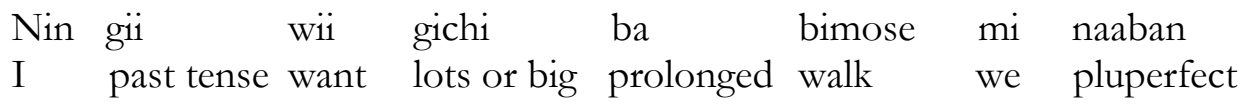

2. Another example:

Maajiimadwebagaasin. The leaves are starting to rustle in the wind. 
TranscUlturAl, vol. 13.1 (2021), 105-106

https://journals.library.ualberta.ca/tc/index.php/tc

$\begin{array}{llll}\text { Maajii } & \text { madwe } & \text { bag } & \text { aasin } \\ \text { starting to } & \text { make sound } & \text { leaf/leaves } & \text { in the wind }\end{array}$

The particles that make up the above sentence/words are not words in their own right. They are particles or morphemes. The Ojibwe translator strings the morphemes tersely and the end result is poetic and true to Ojibwe thought. One is able to reach into one's bag of morphemes and build beautiful words.

So the opportunity to translate these stories about diabetes and ways to overcome it in one's life has been beneficial in two ways for me: 1 . the stories give hope and 2. I was able to reach into my memory and use old words that were there all along and put them on a page. I hope the new learners of the language will be able to use them in the future. Miigwech. 